\title{
Synthesis, Structure, Photoluminescence, Energy Transfer Mechanism and Band Gap of a Terbium-Mercury Complex with a 3-D Framework
}

\author{
Wei-Sheng Lin, ${ }^{1}$ Wen-Tong Chen, ${ }^{2,3^{\star}}$ Han-Mao Kuang ${ }^{2}$ and Hui Luo ${ }^{2}$ \\ ${ }^{1}$ Department of Ecological and Resources Engineering, Fujian Key laboratory of Eco-Industrial Green Technology, \\ Wuyi University, Wuyishan, Fujian 354300, China \\ ${ }^{2}$ Institute of Applied Chemistry, School of Chemistry and Chemical Engineering, Jinggangshan University, Jian, \\ Jiangxi 343009, China \\ ${ }^{3}$ State Key Laboratory of Structural Chemistry, Fujian Institute of Research on the Structure of Matter, \\ Chinese Academy of Sciences, Fuzhou, Fujian 350002, China \\ * Corresponding author: E-mail: wtchen_2000@aliyun.com \\ Tel.: +86(796)8100490; fax +86(796)8100490
}

Received: 07-11-2018

\begin{abstract}
A novel terbium-mercury compound $\left[\mathrm{Tb}(\mathrm{IA})_{3}\left(\mathrm{H}_{2} \mathrm{O}\right)_{2}\left(\mathrm{Hg}_{2} \mathrm{Cl}_{4}\right)\right]_{n} \cdot n \mathrm{HgCl}_{2} \cdot n \mathrm{H}_{2} \mathrm{O}(\mathbf{1}, \mathrm{HIA}=$ isonicotinic acid $)$ was prepared via a hydrothermal reaction and structurally characterized through single-crystal X-ray diffraction technique. This compound is characterized by a three-dimensional (3-D) framework. Photoluminescence experiments with solid-state samples uncovered that this compound can show yellow light emission with the emission peaks at 490, 545, 586 and $621 \mathrm{~nm}$, respectively. These photoluminescence emission peaks are originated from the characteristic emission of the $4 f$ electrons intrashell transition of the ${ }^{5} D_{4} \rightarrow{ }^{7} F_{J}(J=6,5,4,3)$ of the $\mathrm{Tb}^{3+}$ ions. An energy transfer mechanism is expatiated by applying the energy level figure of the terbium ions and isonicotinic acid. This compound possesses a remarkable CIE chromaticity coordinates $(0.3525,0.4032)$. A wide optical band gap of $2.51 \mathrm{eV}$ of the title compound is determined by using the solid-state UV/Vis diffuse reflectance spectroscopy.
\end{abstract}

Keywords: Crystal; hydrothermal reaction; photoluminescence; semiconductor; terbium

\section{Introduction}

For many years, lanthanide materials have gained more and more attention because they can usually show interesting magnetic and photoluminescence performances. ${ }^{1-4}$ Nowadays, researchers from chemistry and material region have accomplished a large number of explorations on lanthanide materials, in order to reveal their practical applications in the fields such as luminescence probes, light-emitting diodes (LEDs), magnetism, electrochemical displays, and so on. ${ }^{5,6}$ Generally speaking, lanthanide materials could display fine photoluminescence emissions, if the $\mathrm{f}-\mathrm{f}$ electronic transition of the lanthanide ions can occur. However, this $\mathrm{f}-\mathrm{f}$ electronic transition is hard to happen because lanthanide ions usually have a low absorption coefficient. It is deemed that some organic ligands can act as an 'antenna' to absorb UV light and effectively transfer the UV light energy to the lanthanide ions; this is so-called 'antenna effect.'? ${ }^{7}$ To our knowledge, the semiconductor performances about lanthanide materials are rarely explored yet when it is compared to the studies on the magnetic and photoluminescence performances. ${ }^{9}$

Terbium ions possess abundant $4 f$ electrons and orbitals, so, coordination compounds containing terbium ions are expected to be able to display attractive photoluminescence properties. ${ }^{10-12}$ Group 12 (IIB) elements (zinc, cadmium and mercury) have also gained a lot of interest due to following reasons: different coordination numbers, interesting photoluminescence and photoelectric performances, and so forth. ${ }^{10-16}$ IIB elements can also be used for semiconductor materials and, up to date, many semiconductor materials with IIB elements have been reported. ${ }^{17-20}$ In recent years, our group keeps 
studying the magnetism, photoluminescence and semiconductor materials. We mainly aim at terbium-IIB-VIIA (VIIA = halogen) materials, in order to explore their crystal structures, magnetism, photoluminescence and band structures. In present work, we report the preparation, crystal structure, photoluminescence, energy transfer mechanism and band structure of a novel terbium-mercury material $\left[\mathrm{Tb}(\mathrm{IA})_{3}\left(\mathrm{H}_{2} \mathrm{O}\right)_{2}\left(\mathrm{Hg}_{2} \mathrm{Cl}_{4}\right)\right]_{n}$. $n \mathrm{HgCl}_{2} \cdot n \mathrm{H}_{2} \mathrm{O}(\mathbf{1}, \mathrm{HIA}=$ isonicotinic acid) with a $3-\mathrm{D}$ framework.

\section{Experimental}

\subsection{Materials and Instrumentation}

The reagents $\mathrm{TbCl}_{3} \cdot 6 \mathrm{H}_{2} \mathrm{O}, \mathrm{HgCl}_{2}$, isonicotinic acid are $\mathrm{AR}$ grade and purchased from commercial source. Photoluminescence measurements were performed on a F97XP photoluminescence spectrometer. UV/Vis diffuse reflectance spectrum was conducted on a TU1901 UV/Vis spectrometer equipped with an integrating sphere.

\section{2. Synthesis of $\left[\mathrm{Tb}(\mathrm{IA})_{3}\left(\mathrm{H}_{2} \mathrm{O}\right)_{2}\left(\mathrm{Hg}_{2} \mathrm{Cl}_{4}\right)_{n}\right.$ $\cdot n \mathrm{HgCl}_{2} \cdot n \mathrm{H}_{2} \mathrm{O}(1, \mathrm{HIA}=$ Isonicotinic Acid)}

$\mathrm{TbCl}_{3} \cdot 6 \mathrm{H}_{2} \mathrm{O}(2 \mathrm{mmol}, 748 \mathrm{mg}), \mathrm{HgCl}_{2}(2 \mathrm{mmol}, 542$ $\mathrm{mg})$, isonicotinic acid $(2 \mathrm{mmol}, 246 \mathrm{mg})$ and $10 \mathrm{~mL}$ distilled water were loaded into a $25 \mathrm{~mL}$ Teflon-lined stainless steel vessel. The vessel was heated at $433 \mathrm{~K}$ for one week. When the vessel was slowly cooled down to room temperature, colorless crystals were collected. The yield was 52\% based on $\mathrm{HgCl}_{2}$.

\section{3. X-ray Structure Determination}

A suitable single crystal was adhered onto the tip of a glass fiber and mounted to a SuperNova CCD diffractometer. The graphite monochromated Mo-Ka radiation is applied for the measurement. The intensity data set was obtained in a $\omega$ scan mode. CrystalClear software was applied to the data reduction and empirical absorption correction. ${ }^{21}$ The crystal structure was solved by using the direct methods. The final structure was refined on $F^{2}$ by full-matrix least-squares using the Siemens SHELXTLTM V5 crystallographic software package. ${ }^{22}$ All non-hydrogen atoms were found on the difference Fourier maps and refined anisotropically (except the lattice water molecule $\mathrm{O} 3 \mathrm{~W}$ ). Because the $\mathrm{O} 3 \mathrm{~W}$ was disordered, it had to be splitted into two sites, namely, O3WA and O3WB. Both O3WA and O3WB were not refined anisotropically and the site occupations were $30 \%$ and $70 \%$ for O3WA and O3WB, respectively. The crystal data and details of data collection and refinement are depicted in Table 1; selected bond lengths and bond angles are shown in Table 2.
Table 1. Crystallographic data and structural analysis

\begin{tabular}{ll}
\hline Formula & $\mathrm{C}_{18} \mathrm{H}_{18} \mathrm{Cl}_{6} \mathrm{Hg}_{3} \mathrm{~N}_{3} \mathrm{O}_{9} \mathrm{~Tb}$ \\
$M_{\mathrm{r}}$ & 1393.74 \\
Crystal system & monoclinic \\
Space group & $P 2_{1} / n$ \\
$a(\AA)$ & $11.9193(4)$ \\
$b(\AA)$ & $9.5228(3)$ \\
$c(\AA)$ & $32.7149(7)$ \\
$\beta\left({ }^{\circ}\right)$ & $94.100(2)$ \\
$V\left(\AA^{3}\right)$ & $3703.81(19)$ \\
$Z$ & 4 \\
Reflections collected & 19656 \\
Independent, observed reflections $\left(R_{\text {int }}\right)$ & $6285,5261(0.0479)$ \\
$d_{\text {calcd. }}\left(\mathrm{g} / \mathrm{cm}^{3}\right)$ & 2.499 \\
$\mu\left(\mathrm{mm}^{-1}\right)$ & 14.756 \\
$F(000)$ & 2504 \\
$T(\mathrm{~K})$ & $293(2)$ \\
$R_{1}, w R_{2}$ & $0.0880,0.2046$ \\
$S$ & 1.135 \\
Largest and Mean $\Delta / \sigma$ & $0.003,0$ \\
$\Delta \rho\left(\right.$ max, min) $\left(\mathrm{e} / \AA^{3}\right)$ & $3.376,-3.576$ \\
\hline
\end{tabular}

Table 2. Selected bond lengths ( $\AA$ ) and bond angles ( $\left.{ }^{\circ}\right)$

\begin{tabular}{lrlr}
\hline \multicolumn{2}{c}{ Bond Lengths (̊̊) } & \multicolumn{2}{c}{ Bond Angles (o) } \\
\hline $\mathrm{Hg}(1)-\mathrm{N}(1)$ & $2.122(5)$ & $\mathrm{N}(1)-\mathrm{Hg}(1)-\mathrm{Cl}(1)$ & $88.44(13)$ \\
$\mathrm{Hg}(1)-\mathrm{Cl}(1)$ & $2.7920(19)$ & $\mathrm{N}(1)-\mathrm{Hg}(1)-\mathrm{Cl}(2)$ & $164.51(14)$ \\
$\mathrm{Hg}(1)-\mathrm{Cl}(2)$ & $2.3051(15)$ & $\mathrm{N}(1)-\mathrm{Hg}(1)-\mathrm{Cl}(3)$ & $90.83(13)$ \\
$\mathrm{Hg}(1)-\mathrm{Cl}(3)$ & $2.8723(16)$ & $\mathrm{Cl}(1)-\mathrm{Hg}(1)-\mathrm{Cl}(2)$ & $101.75(6)$ \\
$\mathrm{Hg}(2)-\mathrm{N}(2)$ & $2.136(5)$ & $\mathrm{Cl}(1)-\mathrm{Hg}(1)-\mathrm{Cl}(3)$ & $93.76(5)$ \\
$\mathrm{Hg}(2)-\mathrm{N}(3)$ & $2.127(4)$ & $\mathrm{Cl}(2)-\mathrm{Hg}(1)-\mathrm{Cl}(3)$ & $100.00(6)$ \\
$\mathrm{Hg}(2)-\mathrm{Cl}(3)$ & $2.7307(16)$ & $\mathrm{N}(2)-\mathrm{Hg}(2)-\mathrm{N}(3)$ & $160.96(18)$ \\
$\mathrm{Hg}(2)-\mathrm{Cl}(4)$ & $2.8477(16)$ & $\mathrm{N}(2)-\mathrm{Hg}(2)-\mathrm{Cl}(3)$ & $104.78(14)$ \\
$\mathrm{Hg}(3)-\mathrm{Cl}(5)$ & $2.3140(18)$ & $\mathrm{N}(2)-\mathrm{Hg}(2)-\mathrm{Cl}(4)$ & $91.88(14)$ \\
$\mathrm{Hg}(3)-\mathrm{Cl}(6)$ & $2.2943(17)$ & $\mathrm{N}(3)-\mathrm{Hg}(2)-\mathrm{Cl}(3)$ & $94.26(12)$ \\
$\mathrm{Tb}(1)-\mathrm{O}(5)^{\mathrm{i}}$ & $2.276(5)$ & $\mathrm{N}(3)-\mathrm{Hg}(2)-\mathrm{Cl}(4)$ & $87.98(12)$ \\
$\mathrm{Tb}(1)-\mathrm{O}(3)^{\mathrm{ii}}$ & $2.313(5)$ & $\mathrm{Cl}(3)-\mathrm{Hg}(2)-\mathrm{Cl}(4)$ & $90.46(5)$ \\
$\mathrm{Tb}(1)-\mathrm{O}(6)^{\mathrm{iii}}$ & $2.334(5)$ & $\mathrm{Cl}(5)-\mathrm{Hg}(3)-\mathrm{Cl}(6)$ & $176.36(7)$ \\
$\mathrm{Tb}(1)-\mathrm{O}(4)^{\mathrm{iv}}$ & $2.354(5)$ & $\mathrm{O}(3)^{\mathrm{ii}}-\mathrm{Tb}(1)-\mathrm{O}(1)^{\mathrm{v}}$ & $73.87(17)$ \\
$\mathrm{Tb}(1)-\mathrm{O}(1)^{\mathrm{v}}$ & $2.360(5)$ & $\mathrm{O}(6)^{\mathrm{iii}}-\mathrm{Tb}(1)-\mathrm{O}(4)^{\mathrm{iv}}$ & $143.57(19)$ \\
$\mathrm{Tb}(1)-\mathrm{O}(2)$ & $2.375(5)$ & $\mathrm{O}(4)^{\mathrm{i}}-\mathrm{Tb}(1)-\mathrm{O}(2)$ & $73.10(18)$ \\
$\mathrm{Tb}(1)-\mathrm{O}(1 \mathrm{~W})$ & $2.491(5)$ & $\mathrm{O}(4)^{\mathrm{iv}}-\mathrm{Tb}(1)-\mathrm{O}(1 \mathrm{~W})$ & $69.47(18)$ \\
$\mathrm{Tb}(1)-\mathrm{O}(2 \mathrm{~W})$ & $2.498(6)$ & $\mathrm{O}(1 \mathrm{~W})-\mathrm{Tb}(1)-\mathrm{O}(2 \mathrm{~W})$ & $126.28(18)$ \\
\hline
\end{tabular}

Symmetry codes: (i) $-x-1 / 2, y+1 / 2,-z+1 \frac{1 / 2}{2}$ (ii) $-x-1,-y+2,-z+$

1; (iii) $x+1 / 2,-y+2 \frac{1}{2}, z-1 / 2$; (iv) $x+1, y, z$; (v) $-x,-y+2,-z+1$.

\section{Results and Discussion}

Compound 1 crystallizes in the space group $P 2_{1} / n$ of the monoclinic system with four formula units in each cell, as uncovered by single crystal X-ray diffraction analysis. The asymmetric unit contains three mercury(II) ions, six chloride ions, one terbium(III) ion, three isonicotinates, two coordinating water molecules and one lattice water molecule. Its molecular structure consists of one $\left[\mathrm{Tb}(\mathrm{IA})_{3}\left(\mathrm{H}_{2} \mathrm{O}\right)_{2}\left(\mathrm{Hg}_{2} \mathrm{Cl}_{4}\right)\right]_{n}$ moiety, one $\mathrm{HgCl}_{2}$ moiety and 
one lattice water molecule, as presented in Fig. 1. All crystallographically independent atoms reside at the general positions.

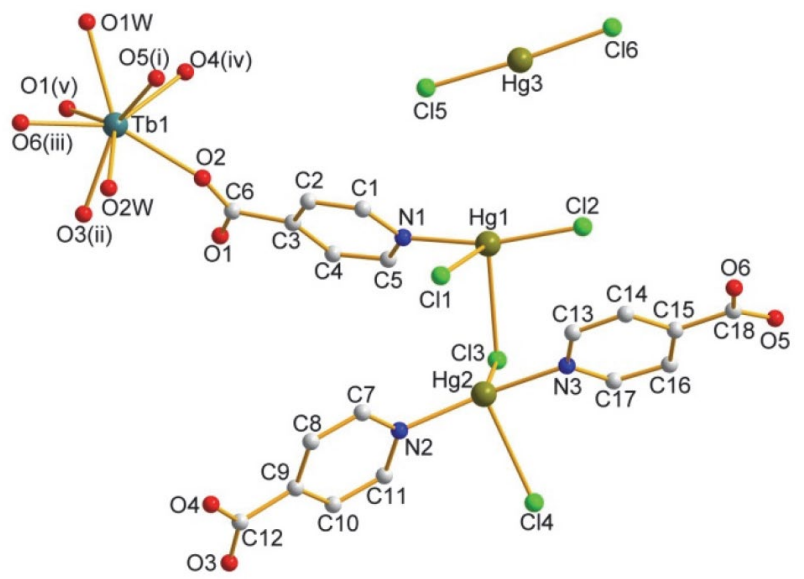

Figure 1. A molecular structure of compound 1 with lattice water and hydrogen atoms being omitted for clarity. Symmetry transformations used to generate equivalent atoms: (i) $-x-1 / 2, y+1 / 2,-z+$ $1 \frac{1}{2}$; (ii) $-x-1,-y+2,-z+1$; (iii) $x+1 / 2,-y+2 \frac{1}{2}, z-1 / 2$; (iv) $x+1$, $y, z$; (v) $-x,-y+2,-z+1$.

There are three crystallographically independent mercury(II) ions existing in compound $\mathbf{1}$. Hg1 ion is surrounded by one nitrogen atom of one isonicotinate and three chloride ions to yield a distorted tetrahedron with the bond angles of $\mathrm{N}-\mathrm{Hg}-\mathrm{Cl}$ and $\mathrm{Cl}-\mathrm{Hg}-\mathrm{Cl}$ being of $88.44(13)^{\circ}-164.51(14)^{\circ}$ and $93.76(5)^{\circ}-101.75(6)^{\circ}$, respectively. $\mathrm{Hg} 2$ ion is coordinated by two nitrogen atoms of two isonicotinates and two chloride ions to yield a distorted tetrahedron with the bond angles of $\mathrm{N}-\mathrm{Hg}-\mathrm{N}, \mathrm{N}-$ $\mathrm{Hg}-\mathrm{Cl}$ and $\mathrm{Cl}-\mathrm{Hg}-\mathrm{Cl}$ being of $160.96(18)^{\circ}, 87.98(12)^{\circ}-$ $104.78(14)^{\circ}$ and $90.46(5)^{\circ}$, respectively. $\mathrm{Hg} 3$ ion is bound by two chloride ions and form a nearly linear mode with the bond angle of $\mathrm{Cl}-\mathrm{Hg}-\mathrm{Cl}$ being of $176.36(7)^{\circ}$. The $\mathrm{Hg}-\mathrm{N}$ and $\mathrm{Hg}-\mathrm{Cl}$ bond lengths locate in the span of

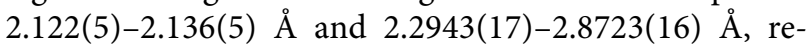
spectively. These bond lengths are normal and comparable with those found in the literature. ${ }^{23-25}$ The terbium ion is coordinated by eight oxygen atoms, of which six are from six isonicotinates and two come from two coordinating water molecules, yielding a slightly distorted square anti-prismatic geometry. The $\mathrm{Tb}-\mathrm{O}$ bond lengths are located in the range of 2.276(5) $\AA-2.498(6) \AA$, which is also normal and comparable with those found in the literature. ${ }^{26-28}$ The neighbouring terbium ions are interlinked by four or two isonicotinates to form a one-dimensional (1-D) Tb-(IA) $)_{4}-\mathrm{Tb}-(\mathrm{IA})_{2}-\mathrm{Tb}-(\mathrm{IA})_{4}$ - chain running along the $b$-axis, as shown in Fig. 2 . The distances between every two neighbouring terbium ions are 4.3996(4) $\AA$ and 5.1233(4) $\AA$. The 1-D Tb-(IA) ${ }_{4}$-Tb-(IA) $)_{2}$-Tb-(IA) $)_{4}$ - chains are interconnected by mercury ions to yield a 3-D framework, as shown in Fig. 3.

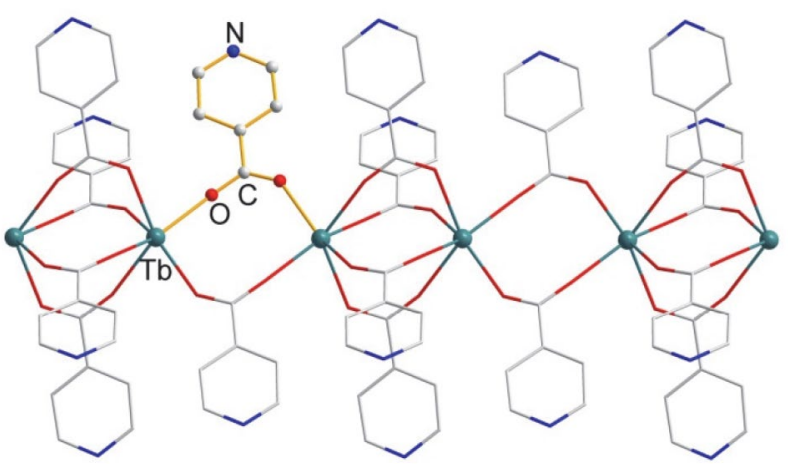

Figure 2. A 1-D Tb-(IA) $)_{4}$-Tb-(IA) $)_{2}$-Tb-(IA) $)_{4}$ - chain in compound 1.

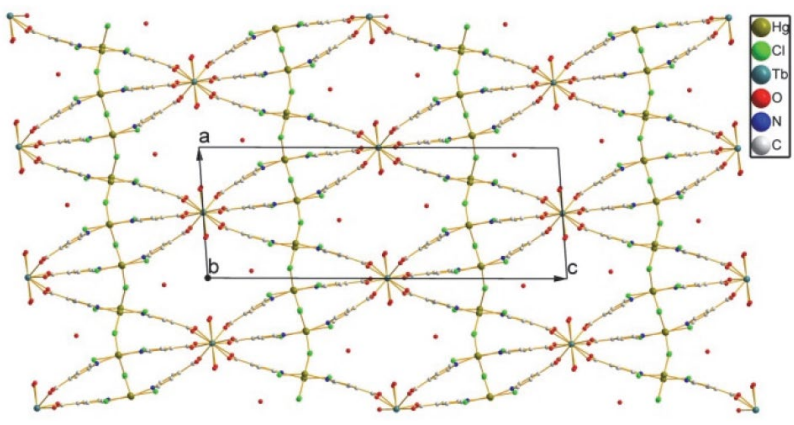

Figure 3. The 3-D framework of compound 1.

In this work, we performed the photoluminescence experiments of compound $\mathbf{1}$ in the solid state and the results of the photoluminescence spectrum are shown in Fig. 4. When it was excited by using the $353 \mathrm{~nm}$ wavelength of UV light, it displays a characteristic photoluminescence spectrum of $\mathrm{Tb}^{3+}$ ions. The photoluminescence diagram contains four sharp emission bands with the strongest one at $545 \mathrm{~nm}$. These peaks reside at 490,545, 586 and $621 \mathrm{~nm}$. They can be ascribed to the characteristic emission of the $4 f$ electrons intrashell transition of the ${ }^{5} D_{4} \rightarrow{ }^{7} F_{\mathrm{J}}(J=6,5$, 4 and 3, respectively) of the $\mathrm{Tb}^{3+}$ ions. ${ }^{29}$ The CIE (Com-

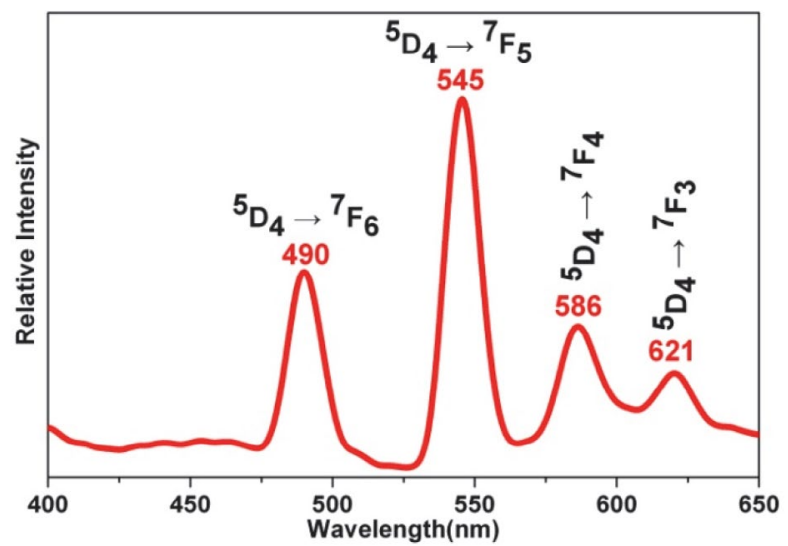

Figure 4. Solid-state photoluminescence spectra of complex 1 measured at room temperature. 
mission Internationale de I’Éclairage) chromaticity coordinates of the title compound are $(0.3525,0.4032)$ which locates in the yellow region, as given in Fig. 5. As a result, compound $\mathbf{1}$ could be expected as a possible yellow light emitting material.

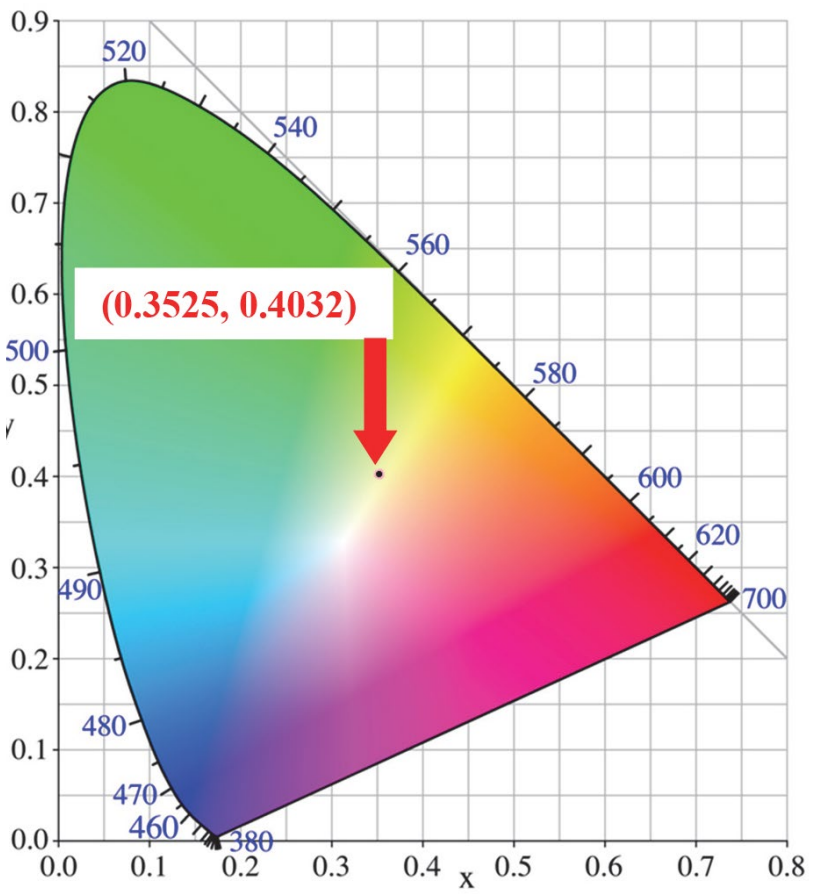

Figure 5. The CIE chromaticity diagram and chromaticity coordinate of the photoluminescence emission spectrum of $\mathbf{1}$.

In order to reveal the energy transfer mechanism of the photoluminescence emission of $\mathbf{1}$, we also carried out the phosphorescence emission spectrum of the isonicotinic acid at $77 \mathrm{~K}$, as given in Fig. 6. The onset of the emission curve of the isonicotinic acid can be estimated to be $434 \mathrm{~nm}$. Therefore, the lowest triplet state energy of isonicotinic acid is calculated to be $23041 \mathrm{~cm}^{-1}$. The energy difference between the lowest triplet state of isonicotinic acid and the resonant energy level of terbium ions $\left({ }^{5} D_{4}\right.$, $20500 \mathrm{~cm}^{-1}$ ) is $2541 \mathrm{~cm}^{-1}$ for compound $\mathbf{1}$, as shown in Fig. 7. Based on the intramolecular energy transfer theory revealed by Sato and Dexter, ${ }^{30-31}$ the intramolecular energy transfer efficiency mainly depends on two processes. The first one is the energy transfer from the lowest triplet energy levels of the ligands to the resonant energy levels of lanthanide centers through the Dexter's resonant exchange interactions. The second on is the reverse energy transfer from the lanthanide centers to the ligands through a thermal deactivation process. The reverse energy transfer process possibly happens easier once the energy difference is small enough. These two energy transfer processes are obviously contrary, even though both of them depend on the energy gap between the lowest triplet energy levels of the ligands and the resonant energy levels of the lanthanide centers. A best energy gap can be estimated to be around $3000 \pm 500 \mathrm{~cm}^{-1}$, as found by the intramolecular energy transfer mechanism. As the above discussions, the energy gap of the terbium ions in compound $\mathbf{1}$ is $2541 \mathrm{~cm}^{-1}$; this is in the range of $3000 \pm 500 \mathrm{~cm}^{-1}$. As a result, compound 1 can be expected to exhibit ideal photoluminescence properties. This prediction is in good line with the photoluminescence emission diagram of the title compound, as given in Fig. 4. From Fig. 4 it can be easily found out that the emission bands are well separated and sharp. Therefore, the above discussions uncover that isonicotinic acid is a good ligand to excite $\mathrm{Tb}^{3+}$ ions for the title compound; namely, it is a suitable "antenna".

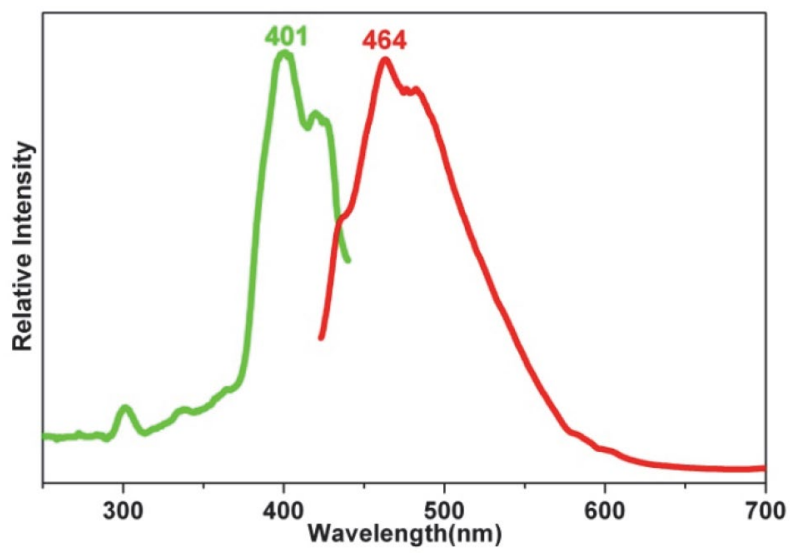

Figure 6. Phosphorescence spectrum of isonicotinic acid measured at $77 \mathrm{~K}$.

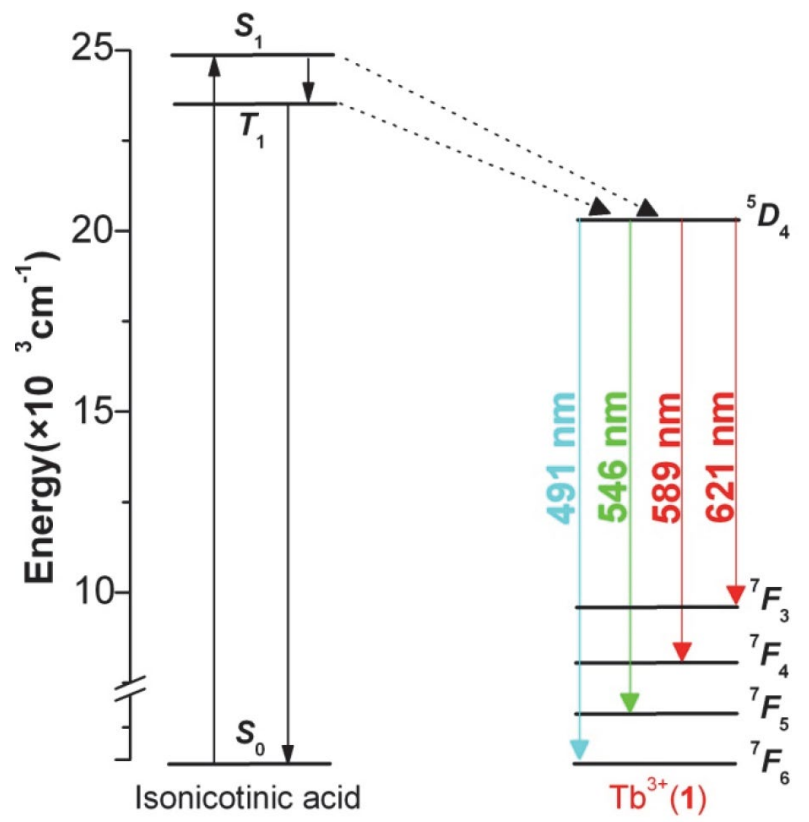

Figure 7. A schematic and partial energy level diagram of the main energy absorption transfer and phosphorescence processes in $\mathbf{1}$ and the isonicotinic acid. 


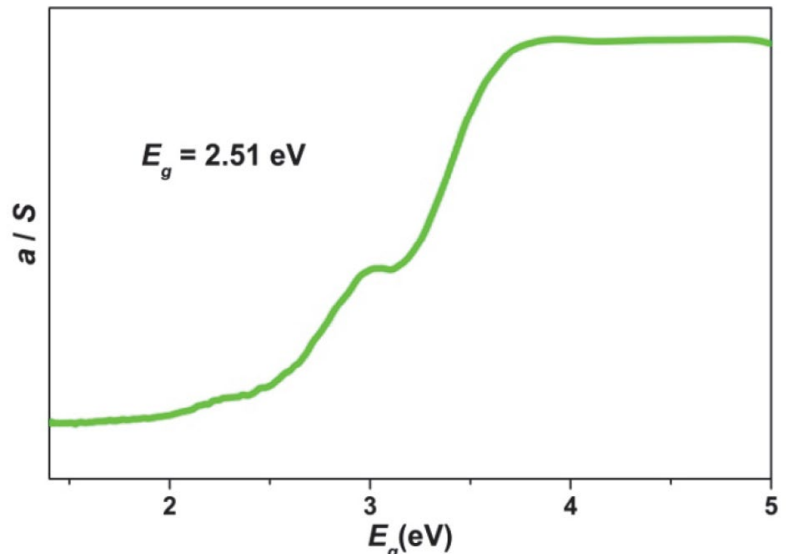

Figure 8. Solid-state UV/Vis diffuse reflectance spectrum of $\mathbf{1}$.

Mercury is a well-known element in semiconductor materials such as $\mathrm{Hg}_{\mathrm{x}} \mathrm{Cd}_{1-\mathrm{x}} \mathrm{Te}$ (i.e. MCT) which is a very important infrared detector in military area. Compound 1 consists of mercury element and, so, it may probably display semiconductor performances. Based on this consideration, we carried out its solid-state UV/Vis diffuse reflectance spectrum under room temperature. The reflectance data set was treated by using the Kubelka-Munk function, i.e. $\alpha / S=(1-R)^{2} / 2 R$. The $R$ is the reflectance, $\alpha$ is the absorption coefficient, while $S$ means the scattering coefficient which is practically wavelength independent if the particle size is larger than $5 \mu \mathrm{m}$. By extrapolating the linear part of the absorption edge of the curve, the optical band gap value can be determined as shown in Fig. 8. The solid-state diffuse reflectance spectrum shows that compound $\mathbf{1}$ has an optical band gap of $2.51 \mathrm{eV}$ and, so, this compound can be classified as a wide band gap semiconductor material. The solid-state diffuse reflectance spectrum diagram exhibits a slow slope of the optical absorption edge, which means an indirect transition process. ${ }^{32}$ This optical band gap of $2.51 \mathrm{eV}$ is clearly smaller than $5.47 \mathrm{eV}$ of diamond which is one of the third generation semiconductor materials; but it is obviously larger than that of $\mathrm{CuInS}_{2}(1.55 \mathrm{eV}), \mathrm{CdTe}(1.5 \mathrm{eV})$ and GaAs $(1.4$ $\mathrm{eV})$ which are well-known highly efficient photovoltaic materials. ${ }^{33-34}$

\section{Conclusions}

In conclusion, a novel terbium-mercury compound was prepared via a hydrothermal reaction and structurally characterized by single crystal X-ray diffraction technique. It is characterized by a 3-D framework. It shows yellow light photoluminescence emission with the emission peaks at $490,545,586$ and $621 \mathrm{~nm}$ which are originated from the characteristic emission of the $4 f$ electrons intrashell transition of the ${ }^{5} D_{4} \rightarrow{ }^{7} F_{J}\left(J=6,5,4,3\right.$, respectively) of the $\mathrm{Tb}^{3+}$ ions. An energy transfer mechanism was expatiated by applying the energy level figure of the terbium ions and isonicotinic acid. It possesses a remarkable CIE chromaticity coordinates $(0.3525,0.4032)$. It also shows a wide optical band gap of $2.51 \mathrm{eV}$. So, this compound is a potential candidate for yellow light photoluminescence and wide band gap semiconductor materials.

\section{Acknowledgements}

We gratefully acknowledge the financial support of the NSF of China (21361013, 31460488), NSF of Fujian (2018J01447), Jiangxi Provincial Department of Education's Item of Science and Technology (GJJ170637), and the open foundation (20180008) of the State Key Laboratory of Structural Chemistry, Fujian Institute of Research on the Structure of Matter, Chinese Academy of Sciences.

\section{Supplementary Material}

Crystallographic data for the structural analysis have been deposited with the Cambridge Crystallographic Data Centre, CCDC 1864724. Copies of this information may be obtained free of charge from the Director, CCDC, 12 Union Road, Cambridge, CBZ 1EZ, UK (Fax: +44-1223336033; email: deposit@ccdc.cam.ac.uk or www: http:// www.ccdc. cam.ac.uk).

\section{References}

1. S. Han, R. Deng, X. Xie, X. Liu, Angew. Chem. Int. Edit. 2014, 53, 11702-11715. DOI:10.1002/anie. 201403408

2. G. Huang, C. Daiguebonne, G. Calvez, Y. Suffren, O. Guillou, T. Guizouarn, B. Le Guennic, O. Cador, K. Bernot, Inorg. Chem. 2018, DOI:10.1021/acs.inorgchem.8b01640.

3. R. F. Mendes, D. Ananias, L. D. Carlos, J. Rocha, F. A. A. Paz, Cryst. Growth Des. 2017, 17, 5191-5199.

DOI:10.1021/acs.cgd.7b00667

4. X.-G. Yi, Z.-X. Zhang, W.-T. Chen, L.-Z. Lin, H.-L. Chen, J. Solid State Chem. 2018, 266, 16-22.

DOI:10.1016/j.jssc.2018.07.004

5. F. Pointillart, O. Cador, B. Le Guennic, L. Ouahab, Coord. Chem. Rev. 2017, 346, 150-175.

DOI:10.1016/j.ccr.2016.12.017

6. J. A. Kitchen, Coord. Chem. Rev. 2017, 340, 232-246. DOI:10.1016/j.ccr.2017.01.012

7. H. J. Zhang, R. Q. Fan, Y. W. Dong, W. Chen, X. Du, P. Wang, Y. L. Crystengcomm 2016, 18, 3711-3724.

8. M. B. Coban, A. Amjad, M. Aygun, H. Kara, Inorg. Chim. Acta 2017, 455, 25-33. DOI:10.1016/j.ica.2016.10.010

9. N. Ahmed, J. Nisar, R. Kouser, A. G Nabi, S. Mukhtar, Y. Saeed, M. H. Nasim, Mater. Res. Express 2017, 4, 065903/1065903/8. 
10. K. P. Zhuravlev, V. I. Tsaryuk, V. A. Kudryashova, J. Fluorine Chem. 2018, 212, 137-143.

DOI:10.1016/j.jfluchem.2018.06.002

11. N. Souri, P. Tian, C. Platas-Iglesias, K. L. Wong, A. Nonat, L. J. Charbonniere, J. Am. Chem. Soc. 2017, 139, 1456-1459. DOI:10.1021/jacs.6b12940

12. X. Chen, L. Zhang, Z. Zhang, L. Zhu, W. Zhu, Cryst. Eng. Comm. 2015, 17, 7856-7865. DOI:10.1039/C5CE01273B

13. M. Arici, Cryst. Growth Des. 2017, 17, 5499-5505.

DOI:10.1021/acs.cgd.7b01024

14. B. Mohapatra, S. Verma, Cryst. Growth Des. 2013, 13, 27162721. DOI: $10.1021 / \operatorname{cg} 4006168$

15. L. N. Wang, L. Fu, J. W. Zhu, Y. Xu, M. Zhang, Q. You, P. Wang, J. Qin, Acta Chim. Slov. 2017, 64, 202-207. DOI:10.17344/acsi.2016.3109

16. P. Wang, Y. S. Wu, X. M. Han, S. S. Zhao, J. Qin, Acta Chim. Slov. 2017, 64, 431-437. DOI:10.17344/acsi.2017.3268

17. Y. Yoshida, H. Ito, Y. Nakamura, M. Ishikawa, A. Otsuka, H. Hayama, M. Maesato, H. Yamochi, H. Kishida, G. Saito, Cryst. Growth Des. 2016, 16, 6613-6630.

DOI:10.1021/acs.cgd.6b01294

18. L. Zhang, H. Lin, Y. Wu, S. Zhuo, Chem. Phys. Lett. 2016, 661, 224-227. DOI:10.1016/j.cplett.2016.08.079

19. Y. Zeng, D. F. Kelley, J. Phys. Chem. C 2016, 120, 17853-17862. DOI:10.1021/acs.jpcc.6b06282

20. T. Uematsu, E. Shimomura, T. Torimoto, S. Kuwabata, J. Phys. Chem. C 2016, 120, 16012-16023.

DOI:10.1021/acs.jpcc.5b12698

21. Rigaku, CrystalClear Version 1.35, Rigaku Corporation, Japan, Tokyo (2002).
22. Siemens, SHELXTL ${ }^{\mathrm{TM}}$ Ver. 5 Reference Manual, Siemens Energy \& Automation Inc., Madison, Wisconsin, USA (1994).

23. H. R. Khavasi, N. Rahimi, Cryst. Growth Des. 2017, 17, 834845. DOI:10.1021/acs.cgd.6b01673

24. R. J. F. Berger, J. Schoiber, U. Monkowius, Inorg. Chem. 2017, 56, 956-961. DOI:10.1021/acs.inorgchem.6b02613

25. Y.-T. Dong, B. Tu, H. Xu, Y.-L. Huang, Q.-L. Zhang, Z.-C. $\mathrm{Hu}, \mathrm{B} . \mathrm{X}$. Zhu, Wuji Huaxue Xuebao (Chinese J. Inorg. Chem.) 2017, 33, 651-658.

26. L.-M. Zheng, J.-X. Liu, J. Solid State Chem. 2017, 245, 45-49. DOI:10.1016/j.jssc.2016.10.008

27. J. Wu, X.-L. Li, L. Zhao, M. Guo, J. Tang, Inorg. Chem. 2017, 56, 4104-4111. DOI:10.1021/acs.inorgchem.7b00094

28. X. Li, T. Li, X. J. Shi, L. Tian, Inorg. Chim. Acta 2017, 456, 216-223. DOI:10.1016/j.ica.2016.11.002

29. M. A. Katkova, V. A. Ilichev, A. N. Konev, I. I. Pestova, G. K. Fukin, M. N. Bochkarev, Org. Electron. 2009, 10, 623-630. DOI:10.1016/j.orgel.2009.02.020

30. S. Sato, M. Wada, Bull. Chem. Soc. Jpn. 1970, 43, 1955-1962. DOI:10.1246/bcsj.43.1955

31. D. L. Dexter, J. Chem. Phys. 1953, 21, 836-850. DOI:10.1063/1.1699044

32. F. Q. Huang, K. Mitchell, J. A. Ibers, Inorg. Chem. 2001, 40, 5123-5126. DOI:10.1021/ic0104353

33. P. Dürichen, W. Bensch, Eur. J. Solid State Inorg. Chem. 1997, $34,1187-1198$.

34. R. Tillinski, C. Rumpf, C. Näther, P. Duerichen, I. Jess, S. A. Schunk, W. Bensch, Z. Anorg. Allg. Chem. 1998, 624, 12851290.

DOI:10.1002/(SICI)1521-3749(199808)624:8<1285::AIDZAAC1285>3.0.CO;2-5

\section{Povzetek}

$\mathrm{S}$ hidrotermalno sintezo smo pripravili novo terbij-živosrebrovo spojino $\left[\mathrm{Tb}(\mathrm{IA})_{3}\left(\mathrm{H}_{2} \mathrm{O}\right)_{2}\left(\mathrm{Hg}_{2} \mathrm{Cl}_{4}\right)\right]_{n} \cdot n \mathrm{HgCl}_{2} \cdot n \mathrm{H}_{2} \mathrm{O}$ (1, HIA = izonikotinska kislina) ter jo strukturno okarakterizirali z monokristalno rentgensko difrakcijo. Spojina tvori tridimenzionalno (3-D) mrežo. Študij fotoluminiscence vzorca v trdnem razkriva, da spojina emitira rumeno svetlobo pri 490, 545, 586 in $621 \mathrm{~nm}$. Ti fotoluminiscenčni emisijski vrhovi so posledica karakteristične emisije znotrajlupinskih prehodov $4 f$ elektronov ${ }^{5} D_{4} \rightarrow{ }^{7} F_{J}(J=6,5,4,3) \mathrm{Tb}^{3+}$ ionov. Mehanizem prenosa energije smo določili z uporabo diagrama energijskih nivojev terbijevih ionov in izinikotinske kisline. Spojina ima kromatične koordinate CIE $(0.3525,0.4032)$. Z UV-Vis difusno odbojno spektroskopijo na trdnem vzorcu smo za spojino določili širok optični pas pri $2.51 \mathrm{eV}$. 